International Journal of Trend in Scientific Research and Development (IJTSRD)

Volume: 3 | Issue: 3 | Mar-Apr 2019 Available Online: www.ijtsrd.com e-ISSN: 2456 - 6470

\title{
Additive Manufacturing of Leaf Spring
}

\author{
K. Vinay Kumar Reddy1, B. Bhaskar'2, Gautam Raj'2, G. Vinay Kumar' \\ ${ }^{1}$ Assistant Professor, ${ }^{2}$ Student \\ 1,2Department of Mechanical Engineering, Guru Nanak Institute of Technology, Hyderabad, Telangana, India
}

\begin{abstract}
How to cite this paper: K. Vinay Kumar Reddy | B. Bhaskar | Gautam Raj | G. Vinay Kumar "Additive Manufacturing of Leaf Spring" Published in International Journal of Trend in Scientific Research and Development (ijtsrd), ISSN: 24566470, Volume-3 | Issue-3, April 2019, pp.1666-1667, URL: https://www.ijtsrd.c om/papers/ijtsrd23 528.pdf

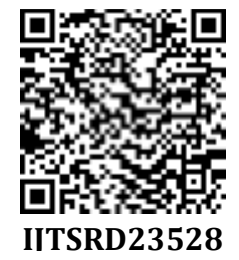

Copyright (C) 2019 by author(s) and International Journal of Trend in Scientific Research and Development Journal. This is an Open Access article distributed under the terms of the Creative Commons

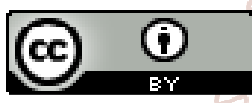
Attribution License (CC BY 4.0) (http://creativecommons.org/licenses/ by $/ 4.0$ )

\section{INTRODUCTION}

A leaf spring is a simple form of spring commonly used forthe suspension in wheeled vehicles. Originally called a laminated or carriage spring, andsometimes referred to as a semielliptical spring or cart spring, it is one of the oldest forms of springing, appearing on carriages in England after 1750 and from there migrating to France.

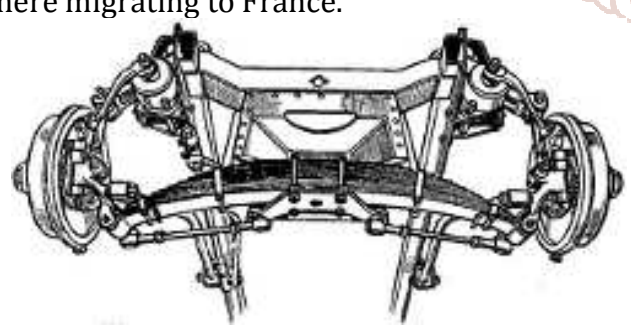

Fig 1. Independent front suspension by transverse leaf

Leaf springs are mainly used in suspension systems to absorb shock loads in automobiles like light motor vehicles, heavy duty trucks and in rail systems. It carries lateral loads, brake torque, driving torque in addition to shock absorbing. The advantage of leaf spring over helical spring is that the ends of the spring may be guided along a definite path as it deflects to act as a structural member in addition to energy absorbing device

According to the studies made a material with maximum strength and minimum modulus of elasticity in the longitudinal direction is the most suitable material for a leaf spring. To meet the need of natural resources conservation, automobile manufacturers are attempting to reduce the weight of vehicles in recent years. Weight reduction can be achieved primarily by the introduction of better material, design optimization and better manufacturing processes.

\section{EXPERIMENTAL WORK}

A. How Leaf Springs Work:

Before you start your towing trip, it's a good idea to go over a brief checklist -- for safety's sake. You take a good look in your mirrors, adjusting them correctly in order to see passing traffic on the road. You've chosen the correct hitch and connected the towing vehicle to the trailer properly. The brake lights and braking systems are working synchronously, assuring you of the ride's legality. With everything loaded up, you're pretty confident the truck is ready for the job,so you head out on the road toward your destination. Once you reach a steady speed, however, the trailer behind your truck starts to bounce and sway a little more than it should. Pulling over to the side of the road, you rack your brains to figure out what you missed. You start to wonder if your cargo weight is maybe too high -- but what can you do about it? In this situation, if there's too much cargo weighing down a towed vehicle, causing everything to rock and sway, the issue may be with the suspension. If a Design and Analysis of Leaf Spring by Using Composite Material for Light Vehicles truck's suspension is too rigid, its wheels will often leave the pavementafter hitting bumps; a good suspension, on the other hand, keeps the wheels on the ground as much as possible. Many towers use leaf springs to stabilize their towed load and 
to keep their cargo grounded. Although you may not ever have heard about or even noticed leaf springs on larger tow vehicles, the technology has been around for centuries and is one of the earliest forms of suspension. Even Leonardo da Vinci used leaf springs in his diagram for a self-propelled car. But how do they work? Are there different types of leaf springs? And how do you install them onto a vehicle?

\section{Design of Leaf Spring}

Model-Mahindra "Model-Ommander 650 Di"

Number of leaf springs $=10$

Overall length of the spring $=2 \mathrm{~L} 1=115 \mathrm{~cm}=1150 \mathrm{~mm}$. Width of leaves $=50 \mathrm{~mm}$

Assuming factor of safety=1.33 Number of full-length leaves = $2=\mathrm{Nf}$

Number of graduated leaves $=8=\mathrm{Ng}$

Number of springs $=10=(\mathrm{Ng}+\mathrm{Nf})$

Centre load $=2 \mathrm{~W}=1910 \mathrm{~kg}$

$2 \mathrm{~W}=1910 \mathrm{X} 10 \times 1.33$ is nearly $25403 \mathrm{~N}$

$2 \mathrm{~W}=25403 / 4=6350.7 \mathrm{~N}$

$2 \mathrm{~W}==6350.7 \mathrm{~N}$

$\mathrm{W}=3200 \mathrm{~N}$ nearly

Material used for leaf spring: structural steel

\section{Prototype Manufacturing}

We used a hand-lay-up method to produce the prototype of a single composite leaf spring. The constant cross section design is used which accommodate continuous reinforcement of fibres and quite suitable for hand lay-up technique. 40 layers of E-glass fibre of $0.4 \mathrm{~mm}$ thick each are used to achieve $17 \mathrm{~mm}$ thickness of the designed leaf spring.

The steps below are followed during prototyping:

$>$ Preparing moulds as per the shape of the leaf spring and the setup.

$>$ Preparing stiffener and clamping plates.

$>$ Cutting fibres to desired dimensions.

$>$ Applying wax/gel on the fibre side of the lower mould for ease of removal.

> Preparing mixture of epoxy resin and polyamine hardener.

$>$ Apply the mixture just above the wax.

$>$ Start laying up the first ply and applythe matrix on it again, repeat the same procedure up to the desired thickness.

$>$ Apply the matrix well on the topmost layer and Cover the upper mould after the wax film is done on its fibre side.

$>$ Put the stiffener on the covered mould and clamp tightly using the plates and c-clamps.

$>$ Allow the composite leaf spring to cure enough at room temperature.

$>$ Remove it from the set up and trim the excess material. tightly using the plates and c clamps.

$>$ Allow the composite leaf spring to cure enough atroom temperature.

$>$ Remove it from the set up and trim the excess material. Figures and tables must be centered in the columns.

\section{Results}

Therefore, there is significant difference in the stresses and deflection in springs under the same static load conditions. Stresses and deflection in structural leaf spring found to be less as compared to the other leaf spring. Totally it is found that the structural leaf spring is the better that of other leaf spring. Therefore, it is concluded.

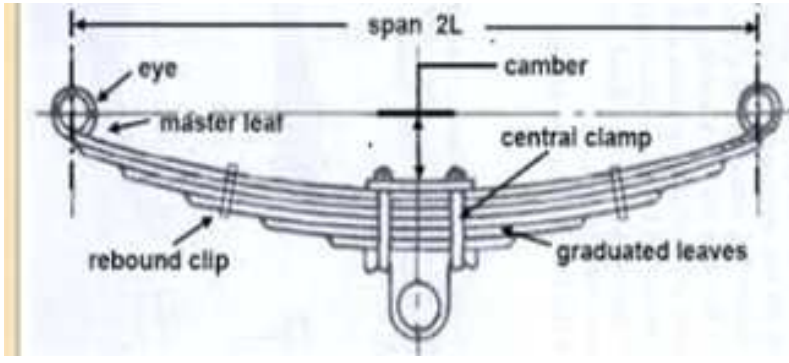

Fig2. Leaf spring model

\section{Conclusion}

1. As leaf spring contributes considerable amount of weight to the vehicle and needs to be strong enough, a single composite leaf spring is designed, and it is shown that the resulting design and simulation stresses are much below the strength properties of the material satisfying the maximum stress failure criterion.

2. From the static analysis results, we see that the vonmises stress in the steel is $352.917 \mathrm{MPa}$. And the vonmises stress in Eglass/ Epoxy is 178.356MPa.

3. Composite mono leaf spring reduces the weight by nearly $84 \%$ for E-Glass/Epoxy.

4. From the fatigue analysis results, the usage factor of Eglass/Epoxy is very much less compared to steel.

\section{References}

[1] M. Venkateshan, D. Helmen Devraj, Design and analysis of leaf spring in light vehicles, IJMER 2249-6645 Vol.2, Issue.1, pp.213-218, Jan-Feb 2012.

[2] R. S. Khurmi and J. K. Gupta Machine Design chapter 23.

[3] U. S. Ramakant \& K. Sowjanya, Design and analysis of automotive multi leaf springs using composite material, IJMPERD 2249-6890 Vol. 3, Issue 1,pp.155162, March 2013,

[4] Rajendran I, Vijayarangan S, Design and Analysis of a Composite Leaf Spring, Journal of Institute of Engineers, India ,vol.-8,2-2002

[5] Dakshraj Kothari,Rajendra Prasad Sahu and Rajesh Satankar Comparison of Performance of Two Leaf Spring Steels Used For Light Passenger Vehicle, VSRDMAP 2249-8303 Volume2 (1), 9-16, 2012

[6] Mr. V. Lakshmi Narayana, Design and Analysis of Mono Composite Leaf Spring For Suspension in Automobiles, IJERT 2278-0181, Vol. 1 Issue 6, August - 2012

[7] Shishay Amare Gebremeskel, Design, Simulation, and Prototyping ofSingle Composite Leaf Spring for Light Weight Vehicle, Global Journals Inc. (USA) 2249-4596, Volume 12 Issue 7, 21- 30, 2012

[8] Manas Patnaik, NarendraYadav, Study of a Parabolic Leaf Spring by Finite Element Method \& Design of Experiments, IJMER 2249- 6645, Vol.2, 1920- 1922, July-Aug 2012

[9] Design and Analysis of E-Glass/Epoxy Composite Monoleaf Spring for Light Vehicle SushilB.Chopade1, Prof.K.M.Narkar2, Pratik K Satav3

[10] Investigation on different Compositions of EGlass/Epoxy Composite and its application in Leaf Spring Suhas1, Jaimon D. Q.2 , Hanumanthraya R. 3 , Vaishak N. L4, Mahesh B. Davanageri5.

[11] Tribological Behaviour of E-Glass /Epoxy \& E-Glass /polyester Composites for Automotive Body Application Esmael Adem1, P.Prabhu 